M. B. Bilò ${ }^{1,2}$, L. Antonicelli2 ${ }^{2}$, M. Carone ${ }^{3}$, F. De Michele ${ }^{4}$, F. Menzella ${ }^{5}$, A. Musarra ${ }^{6}$, S. Tognella ${ }^{7}$, A. $\mathrm{VAghi}^{8}$, C. Micheletto ${ }^{9}$

\title{
Severe asthma management in the era of biologics: insights of the Italian Registry on Severe Asthma (IRSA)
}

${ }^{1}$ Department of Clinical and Molecular Sciences, Università Politecnica delle Marche, Italy ${ }^{2}$ Allergy Unit, Department of Internal Medicine, University Hospital Ospedali Riuniti di Ancona, Italy ${ }^{3}$ Division of Pulmonary Disease, Istituti Clinici Scientifici Maugeri Spa SB, Pavia, and IRCCS of Bari, Bari, Italy ${ }^{4}$ Pneumology I and Respiratory Pathophysiology Unit, A. Cardarelli Hospital, Naples, Italy ${ }^{5}$ Pneumology Unit, Department of Medical Specialties, Arcispedale Santa Maria Nuova, Azienda USL di Reggio EmiliaIRCCS, Reggio Emilia, Italy ${ }^{6}$ Department of Allergology, Casa della Salute di Scilla, Scilla, Reggio Calabria, Italy ${ }^{7}$ Respiratory Unit, Mater Salutis Hospital, AULSS 9 Scaligera, Legnago, Verona, Italy ${ }^{8}$ Respiratory Unit, ASST-Rhodense, Garbagnate Milanese, Milan, Italy ${ }^{9}$ Pulmonary Unit, Integrated University Hospital of Verona, Verona, Italy

\section{KEY WORDS}

Asthma; biologics; eosinophils; IgE; registry.

\section{Corresponding author}

Maria Beatrice Bilò

Department of Clinical and

Molecular Sciences

Università Politecnica delle Marche

Allergy Unit

Department of Internal Medicine University Hospital Ospedali Riuniti di Ancona

via Conca 71

60126 Ancona, Italy

E-mail: m.b.bilo@univpm.it

Doi

10.23822/EurAnnACI.1764-1489.196

\begin{abstract}
Summary
Background. The Italian Registry on Severe Asthma (IRSA) is the most recent and largest registry in Italy. Objective. To improve the knowledge on the clinical and biological features of severe asthma (SA), and to monitor its treatments. Methods. To analyze clinical, functional, inflammatory, and treatment characteristics of severe asthmatics from the IRSA registry. Results. 851 subjects were enrolled. $31.8 \%$ and $64.5 \%$ of patients were submitted to oral corticosteroids (OCS), and monoclonal antibodies (MABs), respectively. At least two comorbidities affected $77.4 \%$ patients. Asthma was uncontrolled in $62.2 \%$ patients. Uncontrolled patients had a higher frequency of exacerbations, and hospitalization, showing a higher eosinophilic phenotype, a greater use of OCS, and being treated with MAB less frequently. However, uncontrolled patients treated with $M A B$ had a lower use of OCS and a lower rate of hospitalization. Comparing $S A$ patients with atopy and without atopy, the latter showed a greater use of OCS, and more frequent nasal polyposis and osteoporosis. Among SA patients with atopy treated with $M A B, 36 \%$ were on a treatment targeting the IL-5 pathway. Conclusions and clinical relevance. This study shows the features of the greatest Italian registry of SA patients, revealing at the time of enrollment a poor disease control, and the use of OCS and MABs in about one third and two thirds of patients, respectively. SA is a complex disease that requires a more precise phenotyping and a greater disease control.
\end{abstract}




\section{Introduction}

Asthma is a chronic and heterogeneous respiratory disease affecting $1-21 \%$ of the population in different countries (1). Even though most of the asthmatic patients are successfully managed according to the acknowledged model of steps therapy, the subset of them affected by severe asthma (SA) can represent a challenge in the medical practice $(2,3)$.

Asthma represents a major economic issue worldwide $(4,5)$. Direct medical expenditures (DMEs), represented by pharmacological treatment, account for $37.5 \%$ of total cost per patient, being the indirect non-medical costs (INMCs) the remaining 62.5\% (6). SA patients can be held accountable for most of both INMCs and DMEs expenditure. With the introduction of the new biologics, their benefit must be weighed against their costs, not just for individual patients but also for the society $(7,8)$. Severe, uncontrolled asthma is related to a large proportion of the burden of the disease (9-11). Moreover, although a wide range of therapeutic options is available, the management of SA frequently remains complex because of the well-known differences in phenotypes and clinical outcome $(3,12,13)$.

Several European and International registries on severe asthma, as a source of real-world data for asthma management, have tried to address these issues (14-24).

In 2017 the Italian Association of Hospital Allergists and Immunologists (AAIITO) and the Italian Thoracic Society (ITSAIPO) proposed the institution of the Italian Registry on Severe Asthma (IRSA), aimed to collect data in SA patients during a 5 -year period in a real life setting (25).

The present analysis of the IRSA data focuses on patients' characteristics in general (lung function, inflammatory and allergic indices, co-morbidities, treatment choices, and asthma control) as well as on specific subgroups of patients at the time of enrollment.

\section{Methods}

In this cross-sectional study, eligible patients were consecutively enrolled to the registry by 71 Units of Allergy and Pulmonology well distributed all over the country (figure 1) with expertise in managing SA, from March 2018 to July 2019. The planned length of follow-up is 5 years; patients attend the Units several times during the year, with a scheduled study visit every 12 months.

As in Italy no national accreditation system for SA Centers does exist, self-referenced accreditation criteria are at the moment only arbitrary; however, the prescription of biologics is accredited by AIFA (the Italian Medicines Agency of the National Health Care System) and applied at regional level. For these reasons, only centers authorized to prescribe biologics were included in the IRSA.
Figure 1 - IRSA Centers: regional distribution.

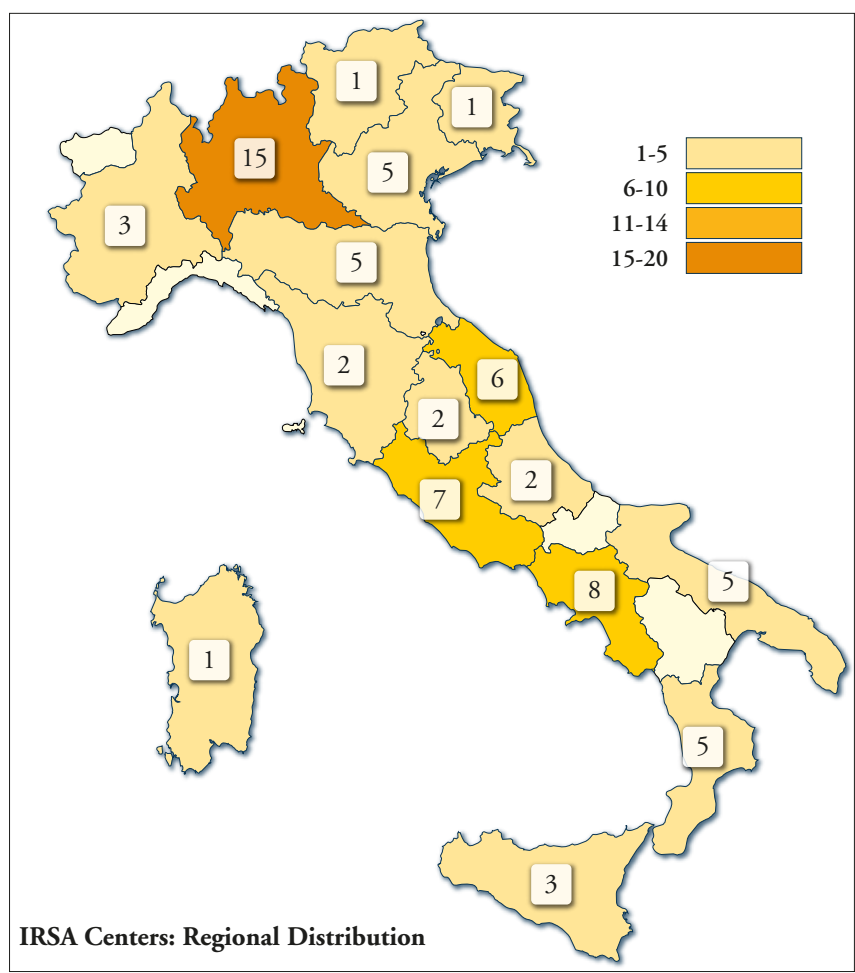

Enrolled patients were male or female $\geq 14$ years of age, with a diagnosis of SA according to the Global Initiative for Asthma (GINA) guidelines (3).

Thespecialistscollected information for each patienton demographics, risk factors, comorbidities, pharmacological treatments, and other functional and clinical data (25). Data were collected on the electronic Case Report Form (eCRF) and registered in the electronic database developed by CINECA (Bologna, Italy, www.cineca.it), a no-profit Consortium made up of 70 Italian Universities, 8 Italian Research Institutions and the Italian Ministry of Education, operating in the management and development of web-based services. All the eCFR were stored online in the central database for data processing and analysis performed on aggregated data.

The study was approved by the Ethical Committee of each centre participating to the registry (positive evaluation of the Central Committee nr. 568-112017 - November 10, 2017).

\section{Statistical analyses}

We conducted descriptive data analyses by tabulating frequencies and percentages (for categorical variables) and mean values, median values, and standard deviations (SD, for continuous variables). For the analysis of comorbidities, descriptive data were also examined graphically through histograms. With reference to comparison between groups (i.e., patients with controlled vs non-controlled asthma; patients with atopic SA versus 
SA without atopy; different treatment groups), categorical data were analyzed using the contingency table analysis with the Chisquare or Fisher's exact test, as appropriate, whereas continuous data were analyzed using a Student's t test, after checking whether data were normally distributed (based on the Shapiro-Wilk statistic), or a Wilcoxon rank-sum test otherwise. All tests were two-sided and a p-value of less than 0.05 was reported as significant. Data analyses were conducted using SAS version 9.4 (SAS Institute, Cary, NC, USA) statistical software.

\section{Results}

\section{General, functional and biological characteristics}

Eight hundred fifty-one patients were enrolled to the registry. Shortly, most were female (61.1\%), being the mean age and the mean Body Mass Index (BMI) 54.8 years and $26.6 \mathrm{~kg} / \mathrm{m}^{2}$, respectively (table I). Most have never smoked, while passive smoking was reported in more than $20 \%$ of the subject (online supplements table IS).

The mean age for asthma symptoms onset was 29 years, the age being > 40 years in $25 \%$ of subjects. Patients were frequently atopic $(73.1 \%)$, meaning at least one sensitization towards the most common Italian triggers of respiratory allergy.

At pre-bronchodilator assessment, the ratio between forced expiratory volume in the first second $\left(\mathrm{FEV}_{1}\right)$ and forced vital capacity $(\mathrm{FVC})\left(\mathrm{FEV}_{1} / \mathrm{FVC}\right)$, the $\mathrm{FEV}_{1}$ percentage predicted $\left(\mathrm{FEV}_{1} \%\right.$ pred.), and the $\mathrm{FVC} \%$ pred. showed a mean value of $69.5 \%$, $70.8 \%$, and $86.4 \%$, respectively (table I). $\mathrm{FEV}_{1} \%$ pred. $\leq 70 \%$ was registered in $53 \%$ of the patients (online supplements table IS). The mean $\mathrm{FEV}_{1}$ at baseline were $1.98 \mathrm{~L}(\mathrm{SD} \pm 0.83)$ and after short-acting bronchodilator $2.24 \mathrm{~L}(\mathrm{SD} \pm 0.90)(78.6 \pm 20.6 \%)$. A peripheral blood eosinophil count $>300 \mathrm{~mm}^{3}$ was reported for $53.7 \%$ of cases, with a mean of $563.4(\mathrm{SD} \pm 1983.4)$ (table I). A mean value of $448.2 \mathrm{Ul} / \mathrm{ml}(\mathrm{SD} \pm 930.6)$ of total immunoglobulin $\mathrm{E}$ ( $\mathrm{IgE}$ ) was found.

\section{Treatments}

At the time of enrollment, 802 patients $(94.2 \%)$ were on treatments with a combination of inhaled corticosteroids (ICS) and long-acting $\beta 2$-Agonists (LABA) (table II); in remaining patients, high dose of ICS plus other controllers or, in few cases, high dose of ICS plus LABA in two different devices were used. In addition to ICS $\pm \mathrm{LABA}$, montelukast, tiotropium, and theophylline were used in $51.9 \%, 39.1 \%$ and $4.9 \%$ of cases, respectively. Oral corticosteroids (OCS) were administered to $31.8 \%$ of the patients (in $62.1 \%$ of them for more than three months). Monoclonal antibodies (MAB) were administered in $64.5 \%$ of patients (omalizumab, mepolizumab and benralizumab). Other treatments are listed in table II.

According to patients treatment association four groups were identified: 1) high dose of ICS + LABA (single or combined): $4.2 \% ; 2$ ) ICS and LABA + other drugs excluding long term (> 3 months)
Table I - Characteristics of IRSA 851 patients.

\begin{tabular}{|c|c|}
\hline General characteristics & Values \\
\hline Female $(\%)$ & 61.1 \\
\hline Age, years $($ mean $\pm S D)$ & $54.8 \pm 13.8$ \\
\hline BMI, $\mathrm{kg} / \mathrm{m}^{2}($ mean $\pm \mathrm{SD})$ & $26.6 \pm 5.0$ \\
\hline $\begin{array}{l}\text { BMI groups }(\%) \\
\text { - Overweight } \\
\text { - Obese }\end{array}$ & $\begin{array}{l}40.9 \\
19.6\end{array}$ \\
\hline Active smokers (\%) & 6.3 \\
\hline Former smokers $(\%)$ & 21.4 \\
\hline Age at symptoms' onset (mean $\pm \mathrm{SD}) \mathrm{y}$ & $29.0 \pm 16.7$ \\
\hline $\begin{array}{l}\text { Age groups at symptoms' onset y }(\%) \\
-\leq 40 \\
->40\end{array}$ & $\begin{array}{l}75.0 \\
25.0\end{array}$ \\
\hline Atopy $(\%)$ & 73.1 \\
\hline Occupational exposure at risk (\%) & 22.2 \\
\hline Occupational related asthma (\%) & 6.0 \\
\hline Biological and functional characteristics & Values \\
\hline Total $\operatorname{IgE}(\mathrm{kU} / \mathrm{L})$, mean $\pm \mathrm{SD}$ & $448.2 \pm 930.6$ \\
\hline $\begin{array}{l}\text { Eosinophils }\left(\mathrm{mm}^{3}\right), \text { mean } \pm S D \\
-\leq 150 \\
-151-300 \\
->300\end{array}$ & $\begin{array}{l}563.4 \pm 1983.4 \\
26.5 \\
19.8 \\
53.7\end{array}$ \\
\hline $\begin{array}{l}\text { ACT score }(\text { mean } \pm \text { SD) } \\
-<20(\%) \\
-20-24(\%) \\
-25(\%)\end{array}$ & $\begin{array}{l}17.2 \pm 4.9 \\
62.2 \\
32.0 \\
5.8\end{array}$ \\
\hline $\mathrm{FEV}_{1}$ bronchodilator withhold $\%($ mean $\pm \mathrm{SD})$ & $70.8 \pm 19.9$ \\
\hline $\mathrm{FEV}_{1}$ post bronchodilator $\%($ mean $\pm \mathrm{SD})$ & $78.6 \pm 20.6$ \\
\hline FVC bronchodilator withhold $\%($ mean \pm SD) & $86.4 \pm 18.3$ \\
\hline FVC post bronchodilator $\%($ mean $\pm S D)$ & $91.8 \pm 17.6$ \\
\hline $\begin{array}{l}\mathrm{FEV}_{1} / \mathrm{FVC} \text { bronchodilator withhold } \% \\
(\mathrm{mean} \pm \mathrm{SD})\end{array}$ & $69.5 \pm 15.3$ \\
\hline $\mathrm{FEV}_{1} / \mathrm{FVC}$ post bronchodilator $\%($ mean $\pm \mathrm{SD})$ & $72.8 \pm 15.7$ \\
\hline Exacerbations & Values \\
\hline $\begin{array}{l}\text { Exacerbation* }(\text { mean } \pm \mathrm{SD}) \\
-1 \text { or more }(\%) \\
\text { *In the previous } 12 \text { months }\end{array}$ & $\begin{array}{l}3.3 \pm 4.3 \\
83.1\end{array}$ \\
\hline $\begin{array}{l}\text { Access to an Emergency Department }(\text { mean } \pm S D) \\
\text { - } 1 \text { or more }(\%)\end{array}$ & $\begin{array}{l}1.8 \pm 2.1 \\
23.6\end{array}$ \\
\hline $\begin{array}{l}\text { Hospitalization }(\text { mean } \pm S D) \\
-1 \text { or more }(\%)\end{array}$ & $\begin{array}{l}1.6 \pm 1.5 \\
17.9\end{array}$ \\
\hline $\begin{array}{l}\text { Access to Intensive Care Department }(\text { mean } \pm S D) \\
-1 \text { or more }(\%)\end{array}$ & $\begin{array}{l}1.6 \pm 1.5 \\
2.7\end{array}$ \\
\hline
\end{tabular}


Table II - Drugs use in 851 patients with severe asthma.

\begin{tabular}{|c|c|}
\hline \multicolumn{2}{|c|}{ Patients (all treatments during the period observed) \% } \\
\hline Combination of ICS and LABA & 94.2 \\
\hline Formoterol + beclometasone & 38.0 \\
\hline Formoterol + budesonide & 19.6 \\
\hline Salmeterol + fluticasone & 18.3 \\
\hline Vilanterol + fluticasone & 13.3 \\
\hline Formoterol + fluticasone & 5.7 \\
\hline Oral corticosteroids (OCS) & 31.8 \\
\hline \multicolumn{2}{|l|}{ Duration of OCS } \\
\hline$<1$ months & 1.1 \\
\hline 1-3 months & 36.8 \\
\hline$>3$ months & 62.1 \\
\hline Monoclonal antibodies & 64.5 \\
\hline Montelukast & 51.9 \\
\hline Tiotropium & 39.1 \\
\hline Theophylline & 4.9 \\
\hline Immunotherapy ongoing & 0 \\
\hline Immunotherapy in the past & 18.3 \\
\hline Thermoplastic treatment ongoing & 1.8 \\
\hline Thermoplastic treatment in the past & 2.9 \\
\hline \multicolumn{2}{|l|}{ Treatments groups $(\%)$} \\
\hline A-ICS and LABA (single or combined) & 4.2 \\
\hline $\begin{array}{l}\text { B-ICS and LABA (single or combined) + others } \\
\text { excluding systemic steroids }>3 \text { months and } \\
\text { monoclonal antibodies }\end{array}$ & 22.7 \\
\hline $\begin{array}{l}\text { C-ICS and LABA (single or combined) } \\
+ \text { monoclonal antibodies }\end{array}$ & 53.5 \\
\hline D-Systemic steroids $>3$ months + any other drugs & 19.6 \\
\hline
\end{tabular}

OCS and MAB: $22.7 \%$; 3) ICS and LABA + Monoclonal antibodies (excluding long term OCS): $53.5 \%$; 4) OCS > 3 months (+ other drugs) $19.6 \%$ (table II).

\section{Comorbidities and association with treatment}

Several comorbidities were reported affecting up to 745 patients (87.5\%); two or more comorbidities were present in $77.4 \%$ of patients. The most observed were chronic rhinosinusitis (51.8\%), gastroesophageal reflux disease (GERD) (43.5\%), nasal polyposis (NP) (42.7\%), hypertension (32.3\%), osteoporosis (19.1\%), and Aspirin intolerance (16.1\%) (figure 2).

The distribution of all the comorbidities in the four treatment groups was different $(\mathrm{p}=0.02)$, with statistically significance for os-
Figure 2 - Co-morbidities in 851 patients with severe asthma.

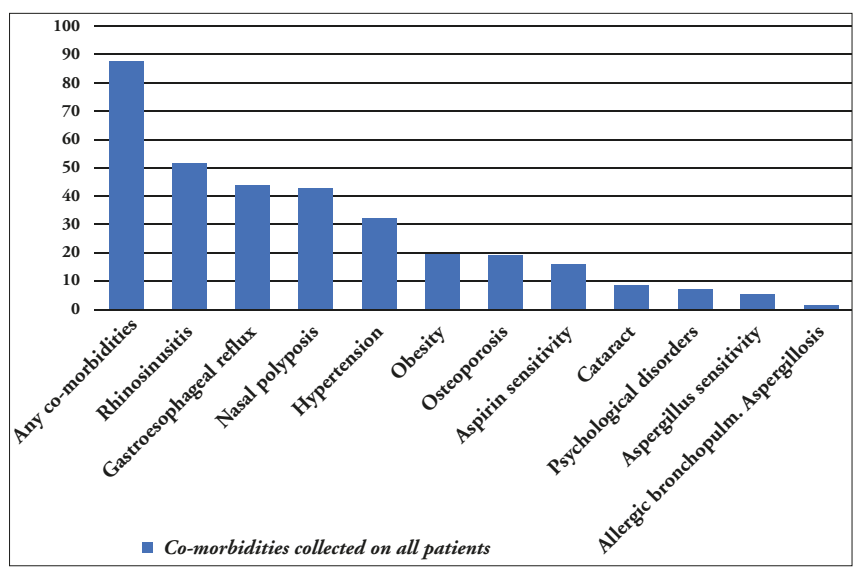

teoporosis and cataract $(\mathrm{p}<0.001)$, which were significantly more prevalent in patients treated with long-term OCS than in three other groups of treatment $(\mathrm{p}<0.001)$. Chronic rhinosinusitis frequency was higher in more severe patients (e.g., those treated with ICS, LABA, MAB, and or OCS), than in patients treated with ICS, LABA and other combinations (online supplements table IIS).

\section{Asthma control and risk factors}

Asthma was defined uncontrolled in $62.2 \%$ of IRSA patients, according to Asthma Control Test (ACT) scoring, with a mean value of 17.2. The mean number of asthma exacerbations in the previous 12 months was 3.3 with $23.6 \%$ of patients having one or more accesses to the Emergency Department and 17.9\% being hospitalized, while access to Intensive Care Department was uncommon (2.7\%) (table I).

Comparing patients with controlled and uncontrolled asthma, some associations $(\mathrm{p}<0.05)$ emerged (table III). Uncontrolled asthmatic patients were more frequent females $(\mathrm{p}=0.02)$, with a $\mathrm{BMI} \geq 30(\mathrm{p}=0.04$.$) ; moreover, they had a higher number$ of exacerbations in the previous 12 months with a mean value of 4.3 ( $p<0.001)$, as well as the use of OCS ( $<<0.001)$ and hospitalization $(\mathrm{p}<0.001)$ were greater.

Among the comorbidities, obesity and psychological conditions were significantly higher in patients with uncontrolled asthma $(22.4 \%$ vs $13.3 \%$ : $\mathrm{p}=0.002$ and $8.5 \%$ vs $4.4 \% ; \mathrm{p}=0.03$, respectively).

Patients with uncontrolled asthma had more frequently an eosinophil count $>300 \mathrm{~mm}^{3}(\mathrm{p}<0.001)$, with a mean of $563.6(\mathrm{SD} \pm$ 1017.4) compared to 391.1 ( $\mathrm{SD} \pm 452.0$ ) of controlled patients ( $\mathrm{p}$ $<0.001)$. The latter were treated with MAB less frequently than controlled patients ( $58.4 \%$ and $75.8 \%$, respectively; $\mathrm{p}<0.001$ ). Comparing uncontrolled patients treated with or without $\mathrm{MAB}$, a significantly lower ACT mean score, a higher hospitalization rate, as well as a higher percentage of patients using of OCS were observed in the latter subgroup (table IV). 
Table III - Characteristics of controlled vs uncontrolled asthma patients.

\begin{tabular}{|c|c|c|c|}
\hline & $\begin{array}{l}\text { Controlled Asthma } \\
\text { N } 301\end{array}$ & $\begin{array}{l}\text { Not Controlled } \\
\text { Asthma N } 550\end{array}$ & P-value \\
\hline Sex, female (\%) & 55.8 & 64.0 & 0.02 \\
\hline $\begin{array}{l}\text { Body Mass Index }\left(\mathrm{kg} / \mathrm{m}^{2}\right)(\text { mean } \pm \mathrm{SD}) \\
-\geq 30\end{array}$ & $\begin{array}{l}26.0 \pm 4.6 \\
14.9\end{array}$ & $\begin{array}{l}26.9 \pm 5.2 \\
22.2\end{array}$ & $\begin{array}{l}0.04 \\
0.01\end{array}$ \\
\hline Hospitalization & 9.3 & 22.6 & $<0.001$ \\
\hline ACT Score mean \pm SD & $21.2 \pm 3.6$ & $15.1 \pm 4.2$ & $<0.001$ \\
\hline $\begin{array}{l}\text { Eosinophils }\left(\mathrm{mm}^{3}\right) \\
->300(\%)\end{array}$ & $\begin{array}{l}391.1 \pm 452.0 \\
45.6\end{array}$ & $\begin{array}{l}563.6 \pm 1017.4 \\
57.9\end{array}$ & $\begin{array}{l}<0.001 \\
<0.001\end{array}$ \\
\hline $\begin{array}{l}\text { Use of OCS (\%) } \\
\text { - Duration of use (users only), mean } \pm \text { SD (months) }\end{array}$ & $\begin{array}{l}16.0 \\
15.0 \pm 19.3\end{array}$ & $\begin{array}{l}40.5 \\
11.1 \pm 24.7\end{array}$ & $\begin{array}{l}<0.001 \\
0.04\end{array}$ \\
\hline $\begin{array}{l}\text { Use of monoclonal antibodies n (\%) } \\
\text { - Omalizumab (n) } \\
\text { - Mepolizumab (n) } \\
\text { - Benralizumab (n) }\end{array}$ & $\begin{array}{l}228(75.8) \\
130 \\
85 \\
13\end{array}$ & $\begin{array}{l}321(58.4) \\
144 \\
155 \\
22\end{array}$ & $\begin{array}{l}<0.001 \\
<0.001 \\
0.99 \\
0.60\end{array}$ \\
\hline Duration of use of monoclonal antibodies (users only) mean \pm SD (months) & $21.4 \pm 22.3$ & $18.6 \pm 25.4$ & $<0.001$ \\
\hline $\begin{array}{l}\text { Treatment group (\%) } \\
\text { - Group D - Systemic steroids > } 3 \text { months (independent of other drugs) }\end{array}$ & 10.0 & 25.0 & $<0.001$ \\
\hline
\end{tabular}

ACT, asthma control test; OCS, oral corticosteroids; SD, standard deviation.

\section{Severe asthma with or without atopy}

Patients with severe asthma without atopy (SAsA) experienced more exacerbations $(p<0.001)$, and showed a higher number of eosinophils $(\mathrm{p}<0.001)$ than those with atopy $(\mathrm{SAwA})$; moreover, they suffered from nasal polyposis $(\mathrm{p}=0.008)$ and osteoporosis $(\mathrm{p}=0.02)$ more frequently $($ table $\mathbf{V})$.

As expected, the mean value of total $\mathrm{IgE}$ was significantly greater in patients with SAwA $(535 \mathrm{IU} / \mathrm{ml})$ than in those with SAsA $(224 \mathrm{IU} / \mathrm{ml})(\mathrm{p}<0.001)$.

Subjects with SAsA reported a higher use of OCS $(41.9 \%$ vs $28.1 \%$; $<<0.001)$, with a longer duration of therapy $(17.0 \pm$ 32.5 months vs $8.9 \pm 16.7$ months; $\mathrm{p}<0.001$ ), with a higher Mepolizumab use $(84.1 \%$ vs $32.4 \%$; $\mathrm{p}<0.001)$ compared to subjects with SAwA (table V).

\section{Discussion}

Data from several national and one international registries on asthmatic patients have been published at the present time (14-24).
IRSA study describes the characteristics of the largest population of Italian SA patients.

Relevant characteristics of this study are: the wide sample size (851 subjects), compared to other Italian and European registries; a wide synoptic view of some clinical, patho-physiologic and hematic values, with the chance to study their correlation and their evolution during the follow up period of 5 years; the use of the three MAB currently available in the market.

Some general, functional, and biological characteristics of IRSA patients were consistent with other European registries (e.g., sex, BMI, smoking habitus, obstructive airway pattern, eosinophilic inflammation) (16-21, 24). Passive smoke exposure was present in $22.2 \%$ of SA patients, highlighting the persistent relevance of smoke as social problem.

An occupational risk was reported by more than $20 \%$ of IRSA patients, even though only $6 \%$ of them received a diagnosis of occupational-related asthma, probably due to the change of the workplace before the progression of the disease. 
Table IV - Characteristics of 550 uncontrolled asthma patients, according to the use of monoclonal antibodies.

\begin{tabular}{|c|c|c|c|}
\hline & $\begin{array}{l}\text { No use of monoclonal } \\
\text { antibodies N } 229\end{array}$ & $\begin{array}{l}\text { Use of monoclonal } \\
\text { antibodies N } 321\end{array}$ & P-value \\
\hline Sex, female (\%) & 62.9 & 64.8 & 0.64 \\
\hline Age at onset of symptoms (mean \pm SD) & $28.9 \pm 17.2$ & $28.7 \pm 15.8$ & 0.91 \\
\hline $\begin{array}{l}\text { Body Mass Index }\left(\mathrm{kg} / \mathrm{m}^{2}\right)(\text { mean } \pm \mathrm{SD}) \\
-\geq 30\end{array}$ & $\begin{array}{l}27.2 \pm 5.6 \\
25.8\end{array}$ & $\begin{array}{l}26.6 \pm 4.8 \\
19.6\end{array}$ & $\begin{array}{l}0.24 \\
0.09\end{array}$ \\
\hline $\begin{array}{l}\text { Exacerbation* }(\%) \\
- \text { Mean } \pm \text { SD } \\
{ }^{*} \text { In the previous } 12 \text { months }\end{array}$ & $\begin{array}{l}96.9 \\
4.7 \pm 5.1\end{array}$ & $\begin{array}{l}93.5 \\
4.1 \pm 4.6\end{array}$ & $\begin{array}{l}0.07 \\
0.12\end{array}$ \\
\hline Hospitalization & 27.1 & 19.3 & 0.03 \\
\hline ACT Score mean \pm SD & $14.4 \pm 4.1$ & $15.6 \pm 4.1$ & 0.001 \\
\hline $\begin{array}{l}\text { Eosinophils }\left(\mathrm{mm}^{3}\right) \\
->300(\%)\end{array}$ & $\begin{array}{l}467.0 \pm 451.3 \\
57.6\end{array}$ & $\begin{array}{l}632.9 \pm 1273.9 \\
58.0\end{array}$ & $\begin{array}{l}0.33 \\
0.60\end{array}$ \\
\hline $\begin{array}{l}\text { Presence of co-morbidities (\%) } \\
\text { - Obesity } \\
\text { - Psychological disorders }\end{array}$ & $\begin{array}{l}87.8 \\
27.4 \\
9.6\end{array}$ & $\begin{array}{l}88.8 \\
18.6 \\
7.7\end{array}$ & $\begin{array}{l}0.72 \\
0.02 \\
0.48\end{array}$ \\
\hline $\begin{array}{l}\text { Use of OCS (\%) } \\
\text { - Duration of use (users only) mean } \pm \text { SD (months) }\end{array}$ & $\begin{array}{l}47.6 \\
9.1 \pm 25.9\end{array}$ & $\begin{array}{l}35.5 \\
13.0 \pm 23.5\end{array}$ & $\begin{array}{l}0.004 \\
0.04\end{array}$ \\
\hline $\begin{array}{l}\text { Treatment group (\%) } \\
\text { - Group D - Systemic steroids > } 3 \text { months } \\
\text { (independent of other drugs) }\end{array}$ & 28.2 & 22.7 & 0.15 \\
\hline
\end{tabular}

ACT, asthma control test; OCS, oral corticosteroids; SD, standard deviation.

In seventy-five per cent of IRSA patients asthmatic symptoms started at age $\leq 40$ years, a value higher compared to other registries $(16,17,19,20,24)$; that is not surprising considering that a high percentage of IRSA patients were atopic (73\%).

Comorbidities were reported by $87.5 \%$ of IRSA patients, most of them being affected by two or more diseases. To go further into the complexity of the management of SA patients, unlike other registers $(16-21,24)$ we included among the comorbidities not only other type-2 diseases (i.e., NP and asthma-related diseases (i.e., GERD)) but also pathologies related to the OCS chronic use (i.e., osteoporosis, cataract). Not surprisingly, osteoporosis and cataract were significantly more prevalent in patients treated with long term OCS.

Almost all IRSA patients were treated with a combination of ICS and LABA. As observed in other registries (17, 19-21), they received montelukast quite frequently $(51.9 \%)$, due at least in part to the high percentage of IRSA patients with NP.

Tiotropium was only used in 39\% of the patients, even though guidelines recommend adding it to ICS and LABA in uncontrolled SA in order to reduce the risk of exacerbations before to start the MAB therapy (3).
About $18 \%$ of patients were treated with allergen specific immunotherapy (AIT) in the past, consistent with both the role of allergy in some IRSA patients, and the contribution of allergists to the registry.

Consistent with the continuing development of the therapeutic options and with the more recent institution of IRSA compared to the other registries, more than $60 \%$ of IRSA patients were treated with biologics, the cost of which in Italy is covered by the national health care system.

In Italy two registries of severe asthma, SANI (21) and IRSA (25), do exist, as in other fields of medicine. Although this can be interpreted as an overlap and a limitation, on the contrary it may represent an opportunity to increase the number of cases, widen the spectrum of information, and check their homogeneity. In this regard it is noteworthy that the use of OCS in our registry $(31.8 \%)$ was comparable to that reported by most European registries $(18,20,24)$ as well as by an Italian pharmacoeconomic study (26), whose range is between $11 \%$ and $45 \%$. The highest percentage of oral steroids use underlined by SANI registry may be due, according to the authors, to the inclusion of more severe asthmatic patients who chronically took OCS in $64 \%$ of cases (21). Howev- 
Table V - Characteristics of patients with or without atopy.

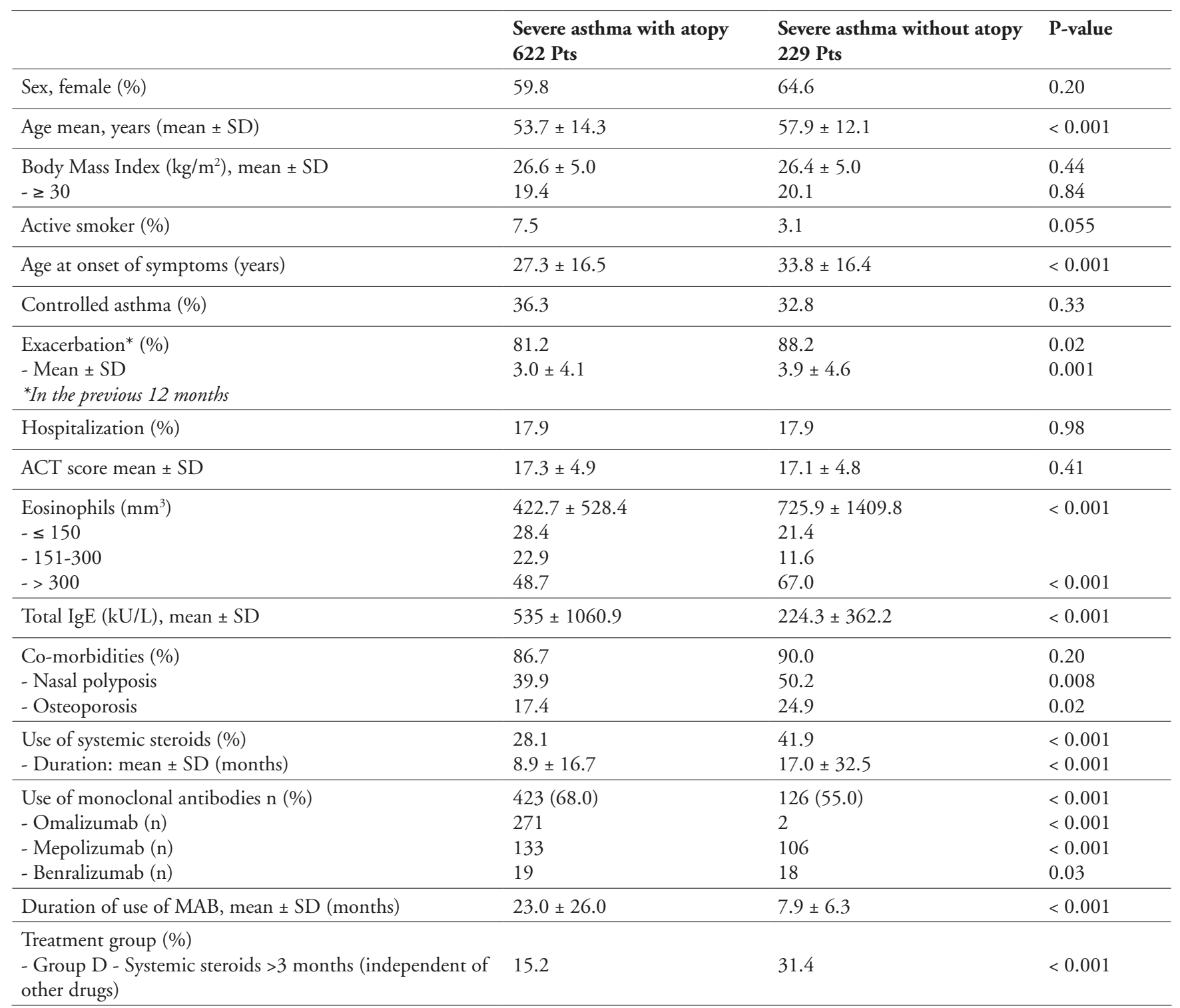

ACT, asthma control test; OCS, oral corticosteroids; SD, standard deviation.

er, without information on the average duration of OCS therapy and/or number of OCS courses, data is difficult to interpret.

At the time of enrollment, asthma was uncontrolled in $62.2 \%$ of IRSA patients, confirmed by ACT scores. The subgroup of uncontrolled SA patients identified a more severe phenotype, in terms of eosinophil count and exacerbation, obesity and psychological conditions. Moreover, they were treated with MAB less frequently and for shorter periods compared to the controlled SA group. This finding was confirmed by the results of another analysis showing that IRSA patients without exacerbations were using $\mathrm{MAB}$ more frequently than those with exacerbations ( $81 \%$ vs 61\%) (data not shown). Other registries and studies showed that patients treated with MAB have a significantly lower risk of exacerbations (20, 27-30).

Moreover, the study showed that more than $50 \%$ of uncontrolled patients were treated with MAB. However, a further analysis of the uncontrolled subgroup indicates that uncontrolled patients not treated with MAB had a greater rate of hospitalization and a lower mean ACT score, as well as a statistically significant higher percentage of these patients were treated with 
OCS than those using MAB. This finding shows that among uncontrolled patients those treated with $\mathrm{MAB}$ are more likely to achieve asthma control and to reduce OCS use in clinical practice, as demonstrated by clinical trials (30).

Patients with SAsA had a more severe disease, in terms of exacerbations, use and duration of OCS, compared to patients with SAwA and they showed an eosinophilic phenotype, and comorbidities like nasal polyposis and osteoporosis. It is noteworthy that among SAwA patients treated with MAB, $64.3 \%$ of them were on a biologic treatment targeting the $\mathrm{IgE}$ pathway, while the remaining patients were on a treatment targeting the IL-5 pathway. The presence of overlapping phenotypes of severe asthma and/or comorbidities may explain these findings (27, 31). Moreover, it can be assumed that some of these patients are atopic, but they do not have an allergic asthma. In both registries and in clinical studies "atopy concept" is often confused with "allergy concept". Asthmatic patients with atopy will not necessarily have an allergic aetiology to their asthma $(32,33)$. The hypothesis that in atopic patients with blood eosinophilia the association between allergen exposure and asthma symptoms/exacerbations as well as age at asthma onset, and presence of fixed airflow obstruction and/or upper airway comorbidities could help to differentiate between severe allergic and severe eosinophilic asthma need to be further investigated (32). However, a recent study in real world confirmed that the overlap between asthma with or without atopy is resolved by doctors, taking into account comorbidities rather than biomarkers (7).

\section{Conclusions}

This study underlines demographic, clinical, functional, and inflammatory features of the greatest number of Italian patients with SA enrolled to a specific clinical registry. Most of severe asthmatic patients in Italy were suffering from more than one comorbidity and had poor asthma control at the time of enrollment, giving a real-world representation of SA. Uncontrolled patients had a higher frequency of exacerbations and hospitalization, indirectly confirming the increased consumption of economic resources. Moreover, they showed a prevalent eosinophilic phenotype, frequently used OCS and were treated with MAB less frequently than controlled subjects. However, among uncontrolled patients, those treated with $\mathrm{MAB}$ are more prone to achieve asthma control and to reduce OCS use in real life. Among SA patients with atopy treated with $\mathrm{MAB}, 36 \%$ were on a treatment targeting the IL-5 pathway. All these findings suggest potential for a more targeted use of biotherapies after proper phenotyping SA patients. Their annual follow-up for five years will monitor the changes that will occur in terms of treatment in relation to a better definition of their phenotype characteristics and of disease control in the era of biologics.

\section{Acknowledgments}

The authors thank Laura Gatti and Andrea Purro (medical writers), Claudio Pelucchi (statistical analysis), and AIPO Ricerche for administrative and technical support.

The authors also thank the contributors to the IRSA project: Artioli Denise (U.O. Pneumologia, ULSS 9 Scaligera, Ospedale Mater Salutis di Legnago, Legnago VR, Italy); Balbi Bruno (U.O. Pneumologia Riabilitativa, Istituti Clinici Maugeri IRCCS, Istituto Scientifico di Veruno, Veruno NO, Italy); Banfi Paolo (U.O. Riabilitazione Pneumologica, Fondazione Don Carlo Gnocchi ONLUS, IRCCS S. Maria Nascente, Milano, Italy); Berra Adriano (U.O. Semplice Allergologia, AOU San Giovanni di Dio e Ruggi d'Aragona, P.O. G. da Procida, Salerno, Italy); Berra Daniele (Ambulatorio di Allergologia e Pneumologia, P.O. di Busto Arsizio, ASST Valle Olona, Busto Arsizio VA, Italy); Bettinzoli Michela (U.O.S.D. Fisiopatologia Respiratoria, P.O. Mellino Mellini di Chiari ASST Franciacorta, Chiari BS, Italy); Bonacina Cristiano (U.O.C. Pneumologia, P.O. Vimercate, ASST Vi-mercate, Vimercate MB, Italy); Bonazza Lucio (U.O. Pneumologia, Ospedale Centrale di Bolzano, A.S. dell'Alto Adige, Bolzano, Italy); Businarolo Elisa (U.O. Pneumologia, Ospedale Santa Maria Bianca di Mirandola-AUSL Modena, Mirandola MO, Italy); Cagnazzo Maria Grazia (U.O.S. Dipartimentale di pneumologia territoriale, P.O. "V. Fazzi” ASL Lecce, Lecce, Italy); Calafiore Paolo (U.O.S.D. Allergologia, P.O. Maria SS. dello Splendore, ASL Teramo, Giulianova TE, Italy); Carone Mauro (U.O. Pneumologia e Riabilitazione Respiratoria, Istituti Clinici Scientifici Maugeri IRCCS, Istituto di Cassano delle Murge, Cassano delle Murge BA, Italy); Casino Giuseppe (U.O. Allergologia e Fisiopatologia Respiratoria, P.O. Piedimonte Matese ASL Caserta, Piedimonte Matese CE, Italy); Cecchi Lorenzo (Centro Allergologia ed Immunologia Clinica, Azienda Sanitaria Toscana, Prato, Italy); Cilia Marcello (Servizio di Allergologia, Casa della salute di Scilla, ASP Reggio Calabria, Scilla RC, Italy); Cremonte Luigi (SSVD Allergologia, Ospedale San Giacomo di Novi Ligure, ASL AL, Novi Ligure AL, Italy); Crociani Lucia (U.O. Pneumologia, Ospedale GB Morgagni-Pierantoni, AUSL Romagna, SSR Emilia Romagna, Forlì FC, Italy); De Donno Giuseppe (S.C. Pneumologia e UTIR, Ospedale Carlo Poma, ASST Mantova, Mantova, Italy); Di Matteo Rosa (U.O. Pneumologia e UTIR, Ospedale S. Maria della Misericordia A.O. di Perugia, Perugia, Italy); Di Stefano Fabio (U.O.C. Pneumologia e Fisiopatologia Respiratoria, P.O Pescara S. Spirito, ASL Pescara, Pescara, Italy); Dottorini Marco (Servizio di Riabilitazione Respiratoria, Centro Servizi Grocco, USL Umbria 1, Perugia, Italy); Farris Battistina (U.O.C. Pneumologia, Ospedale S. Barbara ASSL Carbonia, ATS Sardegna, Iglesias SU, Italy); Franco Cosimo (U.O. Pneumologia, Ospedale Guglielmo Saliceto, AUSL Piacenza, SSR Emilia Romagna, Piacenza, Italy); Gargano Domenico (U.O. Allergologia e Immunologia Clinica, A.O.R.N. San Giuseppe Moscati, Avellino, Italy); Garritani Maria Stella (S.O.D. Allergologia, 
A.O.U. Ospedali Riuniti di Ancona, Ancona, Italy); Gasparini Stefano (S.O.D. Pneumologia, A.O.U. Ospedali Riuniti di Ancona, Ancona, Italy); Harari Sergio (U.O. Pneumologia, Ospedale San Giuseppe Gruppo Multimedica, Milano, Italy); Inciso Giovanni (Ambulatorio Allergologia e Pneumologia, Poliambulatorio di Meta ASL Napoli 3 sud, Meta NA, Italy); Insalaco Giuseppe (Disturbi respiratori del sonno medicina del sonno, CNR Istituto per la ricerca e l'innovazione biomedica (IRIB), Palermo, Italy); Liccardi Gennaro (Ambulatorio di Allergologia Respiratoria, A.O.R.N. "A. Cardarelli”-Napoli, Italy); Lo Schiavo Mario (U.O.C. Allergologia e Immunologia Clinica, Ospedale G. Fucito, A.O.U. S. Giovanni e Ruggi d'Aragona, Mercato S. Severino SA, Italy); Lugatti Emilio (S.O.C. Pneumologia e Fisiopatologia Respiratoria, P.O.U. "Santa Maria della Misericordia”, A.S.U.I. di Udine, Udine, Italy); Maestrelli Matteo (S.C. Pneumologia, Ospedale di Cremona ASST Cremona, Cremona, Italy); Malerba Mario (S.C.D.U. di Pneumologia, P.O. S. Andrea ASL di Vercelli, Vercelli, Italy); Manganello Gianluca (U.O.C. Pneumologia e Fisiopatologia Respiratoria, A.O.R.N. "A. Cardarelli", Napoli, Italy); Manzotti Giuseppina (Poliambulatorio di Allergologia, Casa di Cura Beato Palozzolo, Bergamo, Italy); Marchesani Francesca (U.O.C. Pneumologia, Ospedale Provinciale di Macerata, ASUR Marche Area Vasta 3, Macerata, Italy); Marino Gaspare (U.O.C. Malattie dell'Apparato Respiratorio e UTIR, P.O. S. Antonio Abate ASP Trapani, Erice TP, Italy); Massaccesi Chiara (U.O.C. Pneumologia, P.O. Ospedale "C. e G. Mazzoni" ASUR Marche Area Vasta 5, Ascoli Piceno, Italy); Menzella Francesco (S.C. Pneumologia, Arcispedale S. Maria Nuova IRCCS AUSL Reggio Emilia, SSR Emilia Romagna, Reggio Emilia, Italy); Meriggi Antonio (U.O. Allergologia e Immunologia Clinica, Istituti Clinici Scientifici Maugeri IRCCS Istituto Scientifico di Pavia, Pavia, Italy); Micucci Corrado (U.O.S.D. Pneumologia Ospedale Carlo Urbani ASUR Marche Area Vasta 2, Jesi AN, Italy); Muratore Lionello (U.O.C. Allergologia e Immunologia Clinica, ASL Lecce P.O. "U. Fazzi”, Lecce, Italy); Nucera Eleonora (U.O.C. Allergologia, Policlinico Universitario A. Gemelli, Roma, Italy); Olivieri Mario (U.O. Medicina del lavoro, A.O.U. Integrata di Verona, Verona, Italy); Paddeu Antonio (Riabilitazione Cardio Respiratoria "Paola Giancola", Ospedale S. Antonio Abate di Cantù ASST Lariana, Cantù CO, Italy); Papale Maria (U.O. Fisiopatologia Respiratoria, Istituto Regina Elena Polo Oncologico IRCCS, Istituti Fisioterapici Ospedalieri, Roma, Italy); Pastorello Elide Anna (S.C. Allergologia e ImmunologiaASST Grande Ospedale Metropolitano Niguarda, Milano, Italy); Perra Roberto (Amb. Fisiopatologia Respiratoria, U.O. Pneumologia Territoriale, P.O. R. Binaghi, ASSL Cagliari, ATS Sardegna, Cagliari, Italy); Pini Laura (Centro Asma Grave, P.O. di BresciaMedicina Generale II Mista, ASST Spedali Civili, Brescia, Italy); Pinter Elena (U.O.C. Immunologia Clinica, A.O.U. Policlinico Umberto I, Roma, Italy); Polti Stefano (U.O. Pneumologia, Ospedale San Gerardo ASST Monza, Monza MB, Italy); Quercia Oliviero (Ambulatorio di Allergologia, U.O. Medicina Interna,
Ospedale degli Infermi, AUSL Romagna, SSR Emilia Romagna, Faenza RA, Italy); Ripepi Maria (U.O.C. Pneumologia, Ospedale Metropolitano Bianchi Melacrino Morelli-P.O. Riuniti Reggio Calabria, Reggio Calabria, Italy); Romano Francesco (U.O. Pneumologia, A.O. di Cosenza, Ospedale Mariano Santo, Cosenza, Italy); Romano Annamaria (U.O.S. Pneumologia, A.O.R.N San Giuseppe Moscati, Avellino, Italy); Sabato Eugenio (U.O.C. Pneumologia, P.O. di Summa-Perrino ASL BR, Brindisi, Italy); Savoia Francesca (U.O.C. Pneumologia, Ospedale S. Maria di Ca Foncello, ULSS2 Marca Trevigiana, Treviso, Italy); Scala Raffaele (U.O.C. Pneumologia e UTIP, P.O. San Donato, Azienda USL Toscana Sud-Est, Arezzo, Italy); Scalone Gino (Ambulatorio di Fisiopatologia e Allergologia Respiratoria, Casa della Salute di Chiaravalle Centrale ASP Catanzaro, Chiaravalle Centrale CZ, Italy); Scarantino Giovanna (S.S.D. Allergologia e Fisiopatologia Respiratoria, P.O. S. Elia-ASP Caltanissetta, Caltanissetta, Italy); Scarlata Simone (U.O.C. Gerontologia, Servizio di Fisiopatologia Respiratoria e Endoscopia Toracica, Policlinico Universitario Campus Bio-Medico, Roma, Italy); Scartabellati Alessandro (U.O. Pneumologia e UTIR, Ospedale Maggiore di Crema ASST Crema, Crema, Italy); Tazza Roberto (S.S. Pneumologia Territoriale Distretto di Terni USL Umbria 2, Terni, Italy); Tognella Silvia (U.O.S. Fisiopatologia Respiratoria, Ospedale Orlandi di Bussolengo ULSS9, Bussolengo VR, Italy); Toraldo Domenico (U.O.C. di Riabilitazione Cardiorespiratoria, P.O. A. Galateo ASL Lecce, San Cesario LE, Italy); Triolo Luca (U.O.C. Pneumologia, P.O. San Filippo Neri ASL Roma 1, Roma, Italy); Tripodi Salvatore (Dipartimento di prevenzione ASPRC, Centro Diagnostico Malattie Polmonari Sociali ASP Reggio Calabria, Reggio Calabria, Italy); Vaghi Adriano (U.O.C. Pneumologia, P.O. di Garbagnate Milanese, ASST Rhodense, Garbagnate Milanese MI, Italy); Viglietta Luca (U.O.C. Medicina ad indirizzo pneumologico, Ospedale S. Scolastica ASL Frosinone, Cassino FR, Italy); Zappa Maria Cristina (U.O.C. Pneumologia, Ospedale Sandro Pertini ASL Roma B, Roma, Italy).

\section{Fundings}

The present study was self-funded by AAIITO (Associazione Allergologi Immunologi Italiani Territoriali e Ospedalieri) and ITS-AIPO (Italian Thoracic Society).

\section{Conflict of interests}

Maria Beatrice Bilò declares fees as speaker/lecturer by GlaxoSmithKline, Novartis, Sanofi.

Leonardo Antonicelli declares reseach fundings as Principal investigator by AstraZeneca, GlaxoSmithKline, Novartis, Sanofi. Francesco Menzella declares fees as speaker/lecturer by Angelini, AstraZeneca, GlaxoSmithKline, Novartis, Sanofi.

Antonino Musarra declares Advisory Board fees from AstraZeneca, GlaxoSmithKline, Sanofi Genzyme. 
Silvia Tognella declares fees as speaker/lecturer by Chiesi Farmaceutici, GlaxoSmithKline.

Claudio Micheletto declares fees as speaker/lecturer by A. Menarini, AstraZeneca, Chiesi Farmaceutici, GlaxoSmithKline, Laboratori Guidotti, Novartis, Sanofi.

Mauro Carone, Fausto De Michele and Adriano Vaghi has no partnerships or conflict to disclose.

\section{References}

1. Papi A, Brightling C, Pedersen SE, Reddel HK. Asthma. Lancet 2018;391(10122):783-800

2. Chung KF, Wenzel SE, Brozek JL, et al. International ERS/ATS guidelines on definition, evaluation and treatment of severe asthma. Eur Respir J 2014;43(2):343-73.

3. GINA. Difficult-to-treat and severe asthma in adolescent and adult patients. Diagnosis and management. A GINA pocket guide for health professionals. V2.0 April 2019. Available at: https:// ginasthma.org/wp-content/uploads/2019/06/GINA-2019-mainreport-June-2019-wms.pdf. Last access date: 02.04.2021.

4. Global Burden of Disease Study 2017 (GDB 2017) Data Resources. Available at: https://vizhub.healthdata.org/gbd-compare/. Last access date: 02.04.2021.

5. Nunes C, Pereira AM, Morais-Almeida M. Asthma costs and social impact. Asthma Res Pract 2017;3:1.

6. Accordini S, Corsico AG, Braggion M, et al. The cost of persistent asthma in Europe: an international population-based study in adults. Int Arch Allergy Immunol 2013;160(1):93-101.

7. Llanos JP, Bell CF, Packnett E, et al. Real-world characteristics and disease burden of patients with asthma prior to treatment initiation with mepolizumab or omalizumab: a retrospective cohort database study. J Asthma Allergy 2019;12:43-58.

8. Anderson WC, Szefler SJ. Cost-effectiveness and comparative effectiveness of biologic therapy for asthma: To biologic or not to biologic? Ann Allergy Asthma Immunol 2019;122(4):367-72.

9. Zeiger RS, Schatz M, Dalal AA, et al. Utilization and costs of severe uncontrolled asthma in a managed-care setting. J Allergy Clin Immunol Pract 2016;4(1):120-9.e3.

10. D'Amato G, Vitale C, Lanza M, et al. Near fatal asthma: treatment and prevention. Eur Ann Allergy Clin Immunol 2016;48(4):116-22.

11. O'Neill S, Sweeney J, Patterson CC, et al. British Thoracic Society Difficult Asthma Network. The cost of treating severe refractory asthma in the UK: an economic analysis from the British Thoracic Society Difficult Asthma Registry. Thorax 2015;70(4):376-8.

12. Moore WC, Meyers DA, Wenzel SE, et al. Identification of asthma phenotypes using cluster analysis in the Severe Asthma Research Program. Am J Respir Crit Care Med 2010;181(4):315-23.

13. Newby C, Heaney LG, Menzies-Gow A, et al. British Thoracic Society Severe Refractory Asthma Network. Statistical cluster analysis of the British Thoracic Society Severe refractory Asthma Registry: clinical outcomes and phenotype stability. PLoS One 2014;9(7):e102987.

14. Doberer D, Auer W, Loeffler-Ragg J, et al. The Austrian Severe Asthma Registry. Wien Klin Wochenschr 2015;127(19-20):821-2.

15. Sweeney J, Brightling CE, Menzies-Gow A, et al. British Thoracic Society Difficult Asthma Network. Clinical management and outcome of refractory asthma in the UK from the British Thoracic Society Difficult Asthma Registry. Thorax 2012;67(8):754-6.
16. Korn S, Ubner MH, Hamelmann E, Buhl R. The German severe asthma registry. Pneumologie 2012;66(6):341-4.

17. Schippers D, Hekking P, Sont J, Bel E. Are asthma patients willing to participate in an interactive web-based disease registry? Eur Respir J 2016;48(Suppl. 60):PA1025.

18. Del Carmen Vennera M, Perez de Llano L, Bardagi S, et al. Spanish Registry. Omalizumab therapy in severe asthma: experience from the Spanish Registry - some new approaches. J Asthma 2012;49(4):416-22.

19. Heaney LG, Brightling CE, Menzies-Gow A, Stevenson M, Niven RM, British Thoracic Society Difficult Asthma Network. Refractory asthma in the UK: cross-sectional findings from a UK multicentre registry. Thorax 2010;65(9):787-94.

20. Maio S, Baldacci S, Bresciani M, et al. AGAVE Group. RItA: the Italian severe/uncontrolled asthma registry. Allergy 2018;73(3):683-95.

21. Heffler E, Blasi F, Latorre M, et al. SANI Network. The Severe Asthma Network in Italy: findings and perspectives. J Allergy Clin Immunol Pract 2019;7(5):1462-8.

22. Wang E, Wechsler ME, Tran TN, et al. Characterization of severe asthma worldwide. Data from the International Severe Asthma Registry. Chest 2020;157(4):790-804.

23. van Bragt JJMH, Adcock IM, Bel EHD, et al. on behalf of the SHARP CRC. Characteristics and treatment regimens across ERS SHARP severe asthma registries. Eur Respir J 2020;55(1):1901163.

24. Schleich F, Brusselle G, Louis R, et al. Heterogeneity of phenotypes in severe asthmatics. The Belgian Severe Asthma Registry (BSAR). Respir Med 2014;108(12):1723-32.

25. Micheletto C, Bilò MB, Antonicelli L, et al. Severe asthma in adolescence and adults: a national, multicentre registry in real life. Eur Ann Allergy Clin Immunol 2018;50(5):196-201.

26. Antonicelli L, Bucca C, Neri M, et al. Asthma severity and medical resource utilization. Eur Respir J 2004;23(5):723-9.

27. Novelli F, Latorre M, Vergura L, et al. Xolair Italian Study Group. Asthma control in severe asthmatics under treatment with omalizumab: a cross-sectional observational study in Italy. Pulm Pharmacol Ther 2015;31:123-9.

28. Abraham I, Alhossan A, Lee CS, Kutbi H, MacDonald K. Real-life' effectiveness studies of omalizumab in adult patients with severe allergic asthma: systematic review. Allergy 2016;71(5):593-610.

29. Agache I, Rocha C, Beltran J, et al. Efficacy and safety of treatment with biologicals (benralizumab, dupilumab and omalizumab) for severe allergic asthma: a systematic review for the EAACI guidelines-recommendations on the use of biologicals in severe asthma. Allergy 2020;75(5):1043-57.

30. Agache I, Beltran J, Akdis C, et al. Efficacy and safety of treatment with biologicals (benralizumab, dupilumab, mepolizumab, omalizumab and reslizumab) for severe eosinophilic asthma. A systematic review for the EAACI Guidelines-recommendations on the use of biologicals in severe asthma. Allergy 2020;75(5):1023-42.

31. Chapman KR, Albers FC, Chipps B, et al. The clinical benefit of mepolizumab replacing omalizumab in uncontrolled severe eosinophilic asthma. Allergy 2019;74(9):1716-26.

32. Arbes SJ Jr. Do all asthmatics with atopy have atopic asthma? J Allergy Clin Immunol 2012;130(5):1202-4.

33. Buhl R, Humbert M, Bjermer L, et al. expert group of the European Consensus Meeting for Severe Eosinophilic Asthma. Severe eosinophilic asthma: a roadmap to consensus. Eur Respir J 2017;49(5):1700634. 
Table IS - General, functional and biological characteristics of IRSA 851 patients.

\begin{tabular}{|c|c|}
\hline Characteristics & Values \\
\hline $\begin{array}{l}\text { Ethnicity }(\%) \\
\text { - Caucasian } \\
\text { - Other }\end{array}$ & $\begin{array}{r}98.2 \\
1.8 \\
\end{array}$ \\
\hline $\begin{array}{l}\text { Educational Level }(\%) \\
\text { - Primary or secondary school } \\
\text { - High school } \\
\text { - University }\end{array}$ & $\begin{array}{l}35.4 \\
47.8 \\
16.8\end{array}$ \\
\hline $\begin{array}{l}\text { Area of Italy (\%) } \\
\text { - North } \\
\text { - Centre } \\
\text { - South and Isles }\end{array}$ & $\begin{array}{l}44.2 \\
16.8 \\
39.0\end{array}$ \\
\hline $\begin{array}{l}\text { Passive smoking }(\%) \\
\text { - At home } \\
\text { - At work } \\
\text { - Both }\end{array}$ & $\begin{array}{l}22.2 \\
50.8 \\
39.2 \\
10.0\end{array}$ \\
\hline $\begin{array}{l}\text { Occupational exposure at risk (\%) } \\
\text { - Cleaner } \\
\text { - Agricultural worker } \\
\text { - Chemical worker } \\
\text { - Others }\end{array}$ & $\begin{array}{l}22.2 \\
25.9 \\
25.9 \\
25.3 \\
22.9\end{array}$ \\
\hline Biological and functional characteristics & Values \\
\hline $\begin{array}{l}\mathrm{FEV}_{1} \text { Bronchodilator withhold groups (\%) } \\
-\leq 70 \\
->70\end{array}$ & $\begin{array}{l}52.9 \\
47.1\end{array}$ \\
\hline $\begin{array}{l}\mathrm{FEV}_{1} \text { Post Bronchodilator groups (\%) } \\
-\leq 70 \\
->70\end{array}$ & $\begin{array}{l}34.6 \\
65.4\end{array}$ \\
\hline $\begin{array}{l}\text { Total IgE values (\%) } \\
-<100 \\
-100-300 \\
->300\end{array}$ & $\begin{array}{l}30.8 \\
31.5 \\
37.7\end{array}$ \\
\hline
\end{tabular}

$\mathrm{FEV}_{1}$, forced expiratory volume in the first second; IgE, immunoglobulin E. 
Table IIS - Co-morbidities and their relations with treatments.

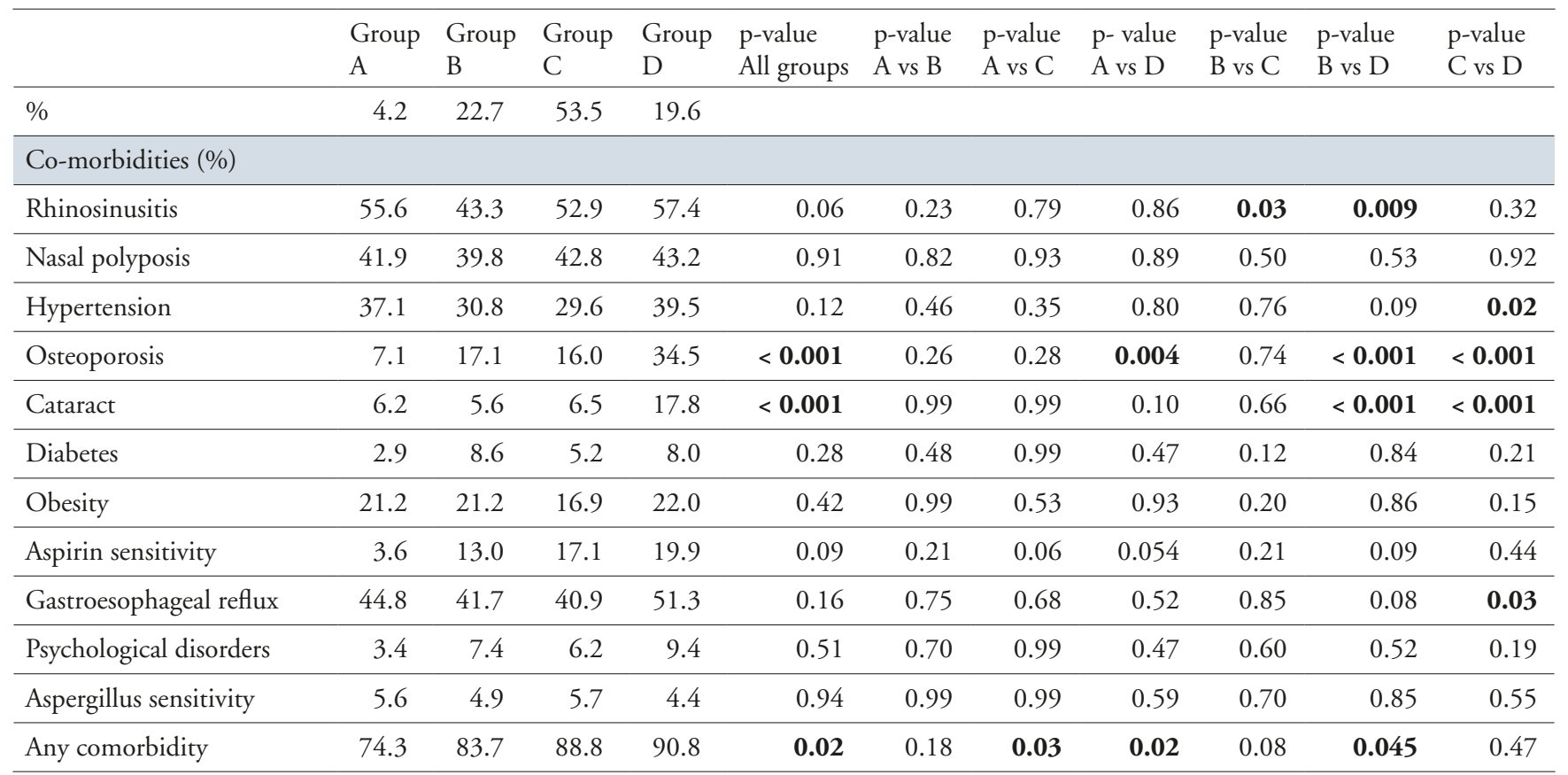

The percentages keep into account the presence of some missing values. 